\title{
社会技術実現に向けての 会話型知識プロセス研究方略
}

The Strategy for Conversational Knowledge Process Support Technologies for Social Technologies

\section{西田豊明}

\author{
${ }^{1}$ 工学博士 京都大学教授 知能情報学専攻 (E-mail: nishida@i.kyoto-u.ac.jp) \\ 社会技術研究システム・ミッションプログラム・統括研究グループ・会話型知識プロセス研究サブグループ(リーダー)
}

\begin{abstract}
社会技術の核心となる情報過程は, 複雑で動的な社会におけるプロセス中心型知識創造過程として特徴 づけられる . 会話型知識プロセス支援技術研究は, 会話という，人間にとって最も自然なコミュニケーシ ヨン手段を中心にしたコミュニティにおけるプロセス中心型知識創造過程支援システムの実現をめざした 取り組みである. 本論文では, これまでの会話型知識プロセス支援技術研究を会話量子化に基づく会話コ ンテンツ流通システムを実現する試みであると特徵づける . 次に , このアプローチを有効に機能させるた めには , 大量の会話コンテンツの理解の支援 , コンテンツ供給のボトルネックの解消 , コンテンツのリア リティの確保，評価手法の確立が必要であることを指摘する．弚の上で, 没入型会話環境, 時空記憶外化 システム, 会話コンテンツ獲得支援, 会話コンテンツ高次利用支援 , 社会知評価パッケージからなる会話 型知識プロセス支援技術確立のための研究方略を提案し，長期的な研究を展望する .
\end{abstract}

キーワード : 会話型知識プロセス , 会話量子化 , 没入型会話環境 , 時空記憶外化システム , 会 話コンテンツ獲得支援，会話コンテンツ高次利用支援，社会知評価パッケージ

\section{1. 会話型知識プロセスに関わる従来の研究状況} 知諳情報通信の観点からみると，社会技術の核心とな る情報過程は , 複杂隹て動的な社会におけるプロセス中心 型知識倉造過程として特徵つけられる. 前論文 ${ }^{1)}$ では， 人々ガ会話を積み重ねることによって共通理解と知識を 構築する過程を会話型知識プロセスと呼び, 会話という， 人間にとって最も自然なコミュニケーション手段を中心 にコミュニティにおける知識創造過程を支援する会話型 知識プロセス支援技術の基本概念とアプローチの仕方に ついて論じた .

会話型知識プロセス研究サブグループでは, リスクコ ミュニケーションを支援するためのコミュニケーション 基盤の構築 , 評価手法の開発 , 展開方法論の確立を平行 して進める学際的なアプローチをとり, 単にコミュニケ ーションツールを開発するだけではなく, リスクコミュ ニケーションに関わる人々の活動全体を視野に入れて， 知識の創出・共有・活用のプロセス全体を見渡して , リ スクコミュニケーションのための相互理解 , 知識共有 , 合意形成をシームレスに支援することを目標とした取り 組みを行ってきた .

この目標を達成するために, 会話型知識プロセス研究 サブグループでは, 図 1 のように , 相互理解のための映 像コミュニケーションツールである VMIS , コミュニテ

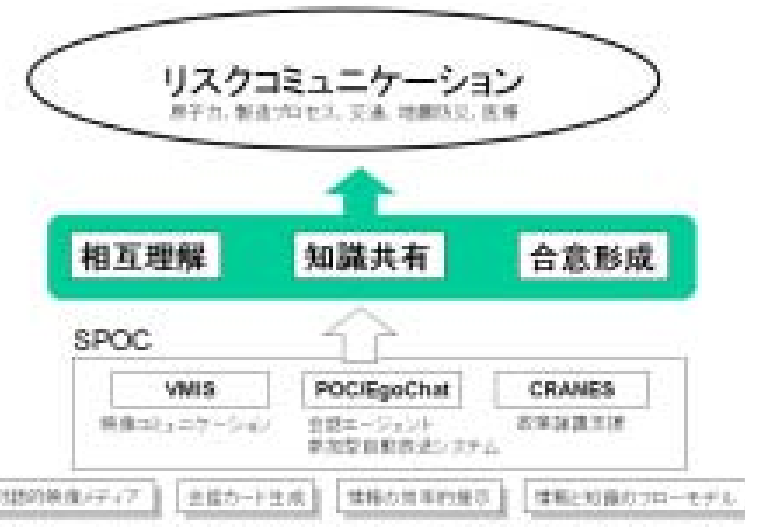

図 $1:$ 会話型知識プロセス研究グループの従来の取り組みの 構图 $^{1)}$

イの知識共有のための会話エージェントシステム EgoChat , 参加型自動放送システム POC, 政策論議支援 のための CRANES を統合する枠組みとしての統合的コ ミュニケーション環境 $\mathrm{SPOC}^{2}$ の研究開発を行うととも に , 会話型知識プロセスを効果的に運用するために , 映 像メディア情報の獲得支援手法, 言語情報のメディア変 換, 情報の効率的提示手法 , 情報と知識のフローモデル についても検討を進めた . 特に, SPOC の研究ては, コ ミュニティのメンバーカ誰でも手軽に会話型コンテンツ 
の収集・編集・流通・閲覧ができるようなメディア環境 の構筑をすすめ, 产の主要部分の開発に成功した ${ }^{1}$.

本論文の役割は, 現在の会話型知識プロセス研究サブ グループの取り組みをレビューした上で, 今後の研究方 略を明示して, 個別の研究を連携させ, 会話型知識プロ セスの研究を構造化することである . 以下の部分では， まず会話型知識プロセス研究サブグループにおいて研究 開発された技術を会話量子化に基づく会話コンテンシ流 通システムを害現する試みとして位置つけて，このアプ ローチを有効に機能させるために今後解決すべき課題を 明らかにする . 次に , 会話型知識プロセス支援技術確立 のための研究方略を提案し, 関連研究を概括するととも に，長期的な研究を展望する。

\section{2. 会話量子化に基づく会話型知識プロセス支援}

会話を中心にしたコミュニティの知識プロセスを支援 するための鍵は, コミュニティメンバー間の時間と空間 を越えた非同期的会話を実現することである.非同期型 の会話型コミュニケーションを実現するためには, コン ピュータが会話参加者のうちの少なくとも一人の会話行 動をある程度シミュレーションして, 当事者がないと きにでも光の会話行動を近似的に再現できなければなら ない. 光のためには, 当該会話参加者の記憶や知識をコ ンピュータのなかに一定の形式て保存し, 会話状況に応 じて適宜修正して, 適当な内容の発話を生成する必要が ある

従来, 自然言語処理や人工知能て研究されてきた対話 システムでは, 意味表現を用いた会話メカニズムが用い られてきた . この方式では, システムの発話のもとにな る記憶の内容をあらかじめ格フレームや意味ネットワー クなどの意味表現や, 意味表現を用いたルールの集まり として表現しておき，実行時に与えられた発話の構文・ 意味解析によって得られた意味表現と比較照合すること によって，応答を生成する .この方式は作りこめば高度 な応答を生成できるが, 多くの場合，作りこみに大きな 労力を要し, 品質保証が大変困難であつた。

これと対照的なアプローチは, 発話場面を兴のまま記 録してボイスメールやムービーメールとして产のまま送 り届けるという方式である .この方式は, 安価であり， 会話の雰囲気も十分伝えられるが, 再利用性がしく, インタラクティブ性も失う。

POC(Public Opinion Channel) $)^{3)}$, EgoChat ${ }^{4)}, \mathrm{SPOC}^{2}$ な どて採用されてきた知識カード系列循環方式は，会話の 生データを使うアプローチに近いものである . ただし , 連続した会話の流れを弚のまま使うのではなく「会話の

\footnotetext{
${ }^{1} 2003$ 年 12 月プレス発表. 科学技術振興機構報 第 13 号: http://www.jst.go.jp/pr/info/info13/index.html
}

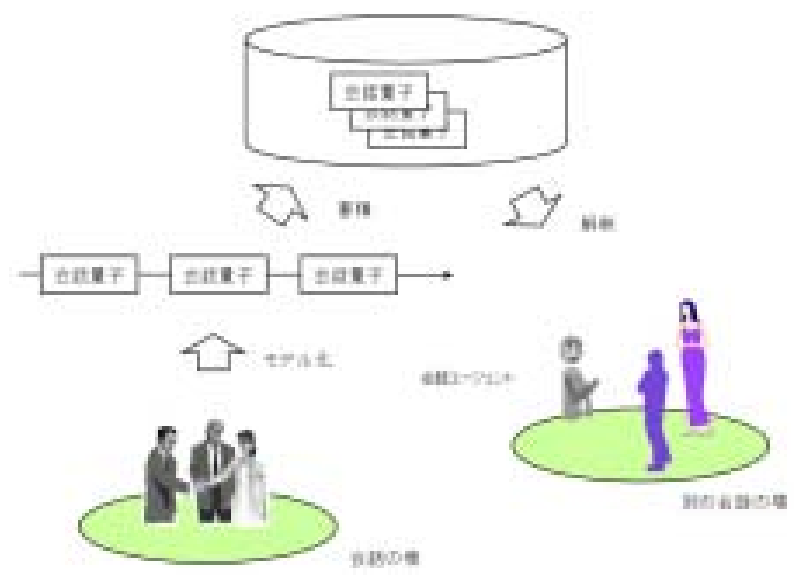

図 2 : 会話量子化に基づく会話型知識プロセス支援技術

粒」の離散的な流れとして会話を近似し，集積して，別 の会話の場に適用することによって , 再利用性とインタ ラクティフ性を高めていた．以下では,「会話の粒」を「会 話量子」, 会話量子の概念を使った会話システムの構成法 を「会話量子化のアプローチ」(図2) と呼び, より抽象 的な観点から，乥の性質を分析する。

会話量子化のアプローチにおける個々の会話量子は， 会話の場において知覚された現象のうち, 有意味と認め られたイベントの連鎖をひとまとめにしたものである . 何を有意味と認めるかは, 会話量子を生成する参加者や 観察者に依存する . 会話を取り巻く状況のうち, 会話量 子生成者が会話に関連すると認めたものは会話量子の中 に背景情報として組み込まれるが, 光うでないと判断さ れたものは，暗黙のまま残される .

会話量子の解釈は, 与えられた会話量子からもとの会 話がどのようなものであつたかという情報を取り出すプ ロセスである . 会話量子の解釈には, 会話量子化の対象 となる会話の模樣をビデオのように再現するだけでなく， その一部を他者や会話エージェントによる発話に置き換 えることも含まれている、会話量子は, 生成者の背景知 識や意図に依存して生成されたものであり，同じ会話量 子でも解釈者の背景知識や視点によって異なる情報力発 生するという，解釈の不確定性を内包している点に注意 しなければならない この問題の分析は複雑になるので, 今後の研究にゆだねることとする .

会話量子化のアプローチは生データに近い状態でのデ 一夕保持を前提としているので, 従来の方法と比較する とコンテンツ制作の大きなコストダウンか望める上に , 現在まだ末完成の音声認識, ジェスチャ認識技術, 表情 認識, 言語処理, 人工知能技術でも, 会話メディアのも つ利点を生かした非同期型のネットワークコミュニケー ションを実現できる . 会話量子はある程度の文脈情報を 保持しているので, もとの文脈と類似の文脈があればあ る程度产の内容か了解できるという意味で, 技術的なほ 
ころびに強く，状況認識の不完全性を許容する . 会話量 子はもとの会話の持つ繊細さを保持できるので, 乥れ自 体の品質保持がある程度可能である . 会話の流れに応じ て会話量子を供給することにより，比較的ゆっくりした ターンの会話であれば十分な品質か確保できる．

会話量子のサイズが大きくなると，会話量子の解釈の 文脈独立性は向上するが, 再利用性は低下する . 会話量 子のサイズを調整することにより，会話量子の自立性と 再利用性の間の適切なトレードオフを見出すことか求め られる . 会話量子の適切なサイズについてはまた議論と 調査の余地はあるが, 経験的には1個の会話量子は, 日 本語の場合は 70 文字前後+参照イメージくらいで表せ るであろうと思われる .

従来の知識カード系列循環方式ては, テキストデータ と 1 個の参照映像から構成されるデータ構造である知識 カードを用いて会話量子を表現した · 知識カードの集ま りによる会話の表現を総称して会話コンテンツと呼ぶ . なかでも，会話を題材とする会話コンテンツは視聴者を 引き込む力か強く, 会話コンテンツの重要なサブセット となっている。

会話量子をばらばらに蓄積するだけでは, 人間の中長 期の会話をシミュレートすることは困難であるので, 会 話量子の流れを制御するためのしくみを用意しておく必 要がある.これまでの研究開発では, 短期的な会話の流 れを5〜20 個程度の固定された会話量子の系列（ストー リーと呼ぶ)で表現し，長期的な会話の流れに関するポ リシーを適当な言語を用いて表現することか試みられて きた 、フローの制御機構をもつ会話量子の伝達経路を知 識チャンネルと呼ぶ（図 3a).

会話量子の量がある程度の規模になり，フローも複雑 になると，乥の全体像を俯敢できるようにする必要があ る. 新聞や杂隹志などにみられる番組表の形式を用いたフ ローの動的な可視化と, グラフ構造の表示による可視化 などが考えられるが, こうした会話量子の集積の空間的 表現を景観(landscape)と呼ぶ .

また , 非同期な会話においても双方向性力確保されね ばならない, 例えば，遠隔非同期講義に適用する場合は， 教師がコンテンツを更新したことか生徒に伝わり，生徒 からの質問や意見力教師にタイムリーに伝わることが保 障されていなければならない .このように, 非同期の会 話チャンネルは, 会話参加者の動静を適切に伝達するア ウェアネスの機構を伴うものでなければならない (図 3b) .

以上をまとめると図 $3 c$ のような全体像になる :システ ム全体は, 知識カードの作成・閲覧を行うための知識力 ードエディタ(knowledge card editor), 知識カードの蓄積 ・ 配信をするための知識カードサーバ(knowledge card server), 与えられた知識カードに基ついて人間との会話

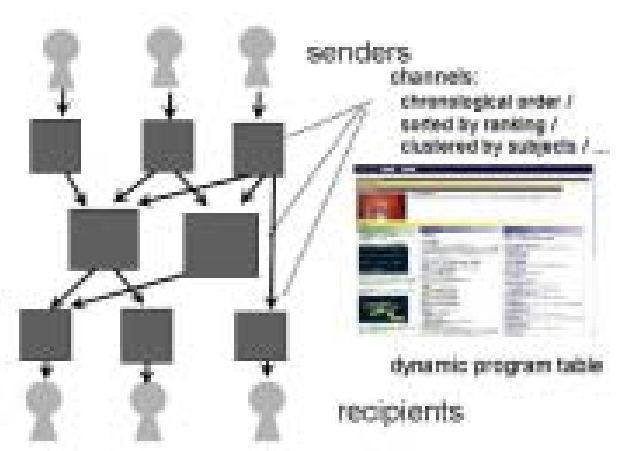

(a) 会話量子の系列制御 一 知識チャンネル

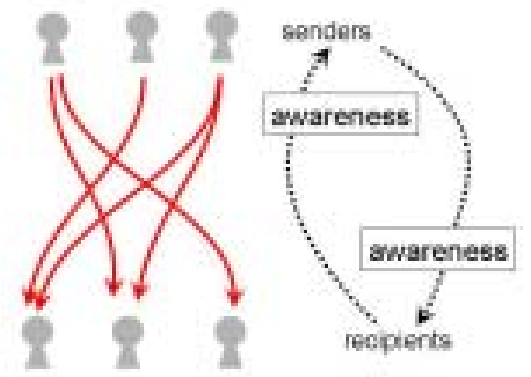

(b) アウェアネスの提供

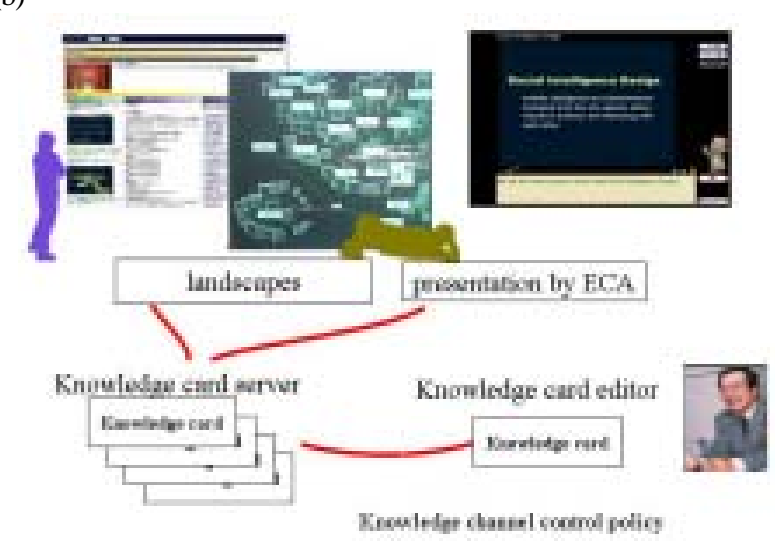

(c) 会話量子化の実装としての知識カード系列循環方式

図 3 : 会話量子化に基づく会話型知識プロセス支援技術

を実現するための会話エージェント (embodied conversational agent, ECA), 知識カードサーバに蓄積され た知識カードの集合の景観の表示と編集を行うための景 観ブラウザ(landscape browser)などから構成される .これ らのコンポーネントの間に , アウェアネスの伝達をとも ない, 知識カードを戦略的に配信する知識チャンネルが 張り巡らされる。

上に述べたアプローチは, 講義や社会技術研究システ ムのミッショングループの研究成果のインタラクティブ な発表などに用いられている (表1).

\section{3. 会話型知識プロセス研究に関わる新たな課題}

会話量子化に基づく会話コンテンツ流通システムの実 用化と実証の過程を経ることによって，会話型知識プロ セスを有効に機能させるためには, 大量の会話コンテン 
表 $1:$ 会話量子化によるコンテンジ制作 ${ }^{34)}$

\begin{tabular}{|c|c|c|}
\hline システム & 用途 & 概要 \\
\hline $\mathrm{POC}$ & $\begin{array}{l}\text { 地域コミュニテ } \\
\text { 支援 }\end{array}$ & 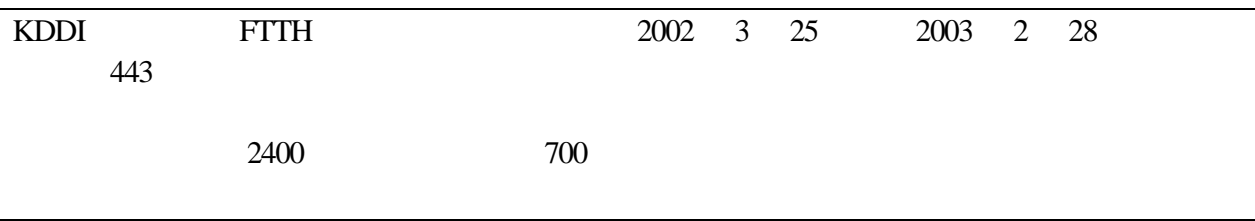 \\
\hline POC & 講義 & 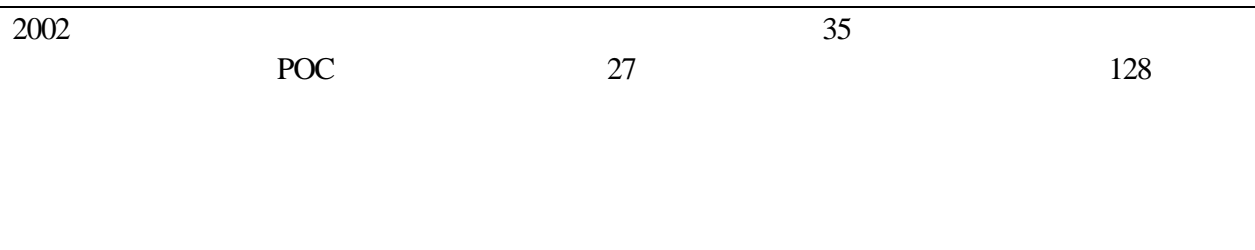 \\
\hline POC & 野外活動場面 & 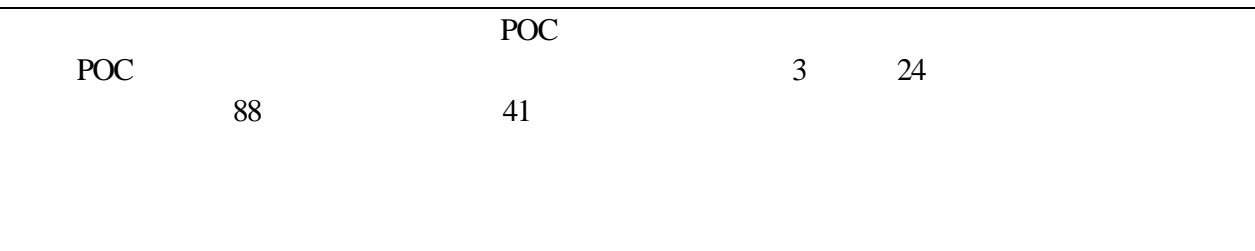 \\
\hline EgoChat & 講義 & 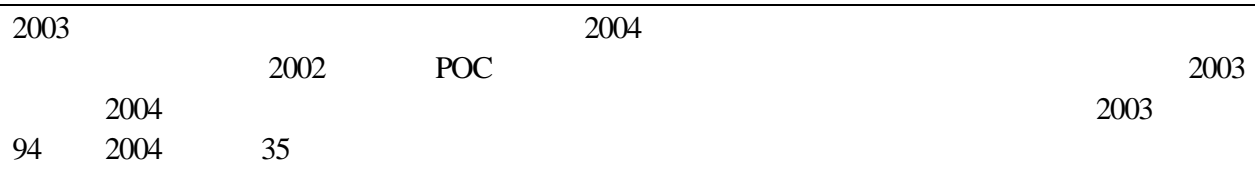 \\
\hline EgoChat & 社会技術 & 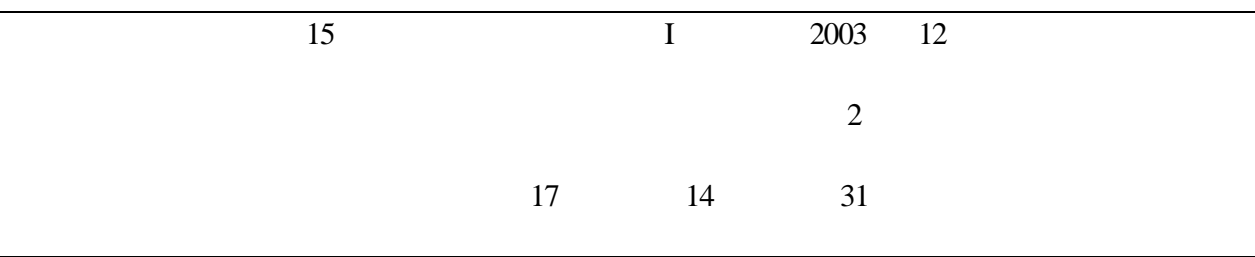 \\
\hline EgoChat & $\begin{array}{l}\text { 電子機器マニュ } \\
\text { アル }\end{array}$ & 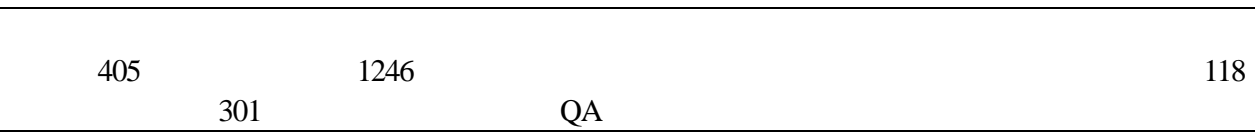 \\
\hline
\end{tabular}

ツの理解の支援 , コンテンツの供給のボトルネックの解 消, コンテンツのリアリティの確保, 評価手法の確立が 必要であることか明らかになった .

\section{1. 大量の会話コンテンツの理解の支援}

会話コンテンツ流通システムの実用化か淮むにつれて， 大量の会話コンテンツか泩成され，蓄積されるようにな つてきた . 実用化が十分に進んだとき，個人の保有する 会話量子の個数を予測することは困難であるが, メール と同樣に単純に 1 日に 100 個ずつ制作されるとすれば , 1 年で 3 万個強, 80 年で 300 万個というオーダーになる . 1000 人のコミュニティで各参加者が自分の会話量子の $1 \%$ を流通させるとすれば, 年間約 30 万個強の会話量子 が流通することになる .

これだけの量の会話量子のすへててを後て検索したり再 利用する必要は必ずしもないが, 弚のなかにどのような 内容の会話量子があり, 自分とどのように関わりがある かという概要か掌握できなければ, 個人およびコミュニ ティの知識倉造への活用は期待できない .

大量のデータを扱うための手法としては, タグ付け技 術, オントロジー技術, 検索技術, 可視化技術などが知 られている。
タグ付け技術は，データにタグ付けを行って効用を高 めようとするものであるが, データへのタグ付けには一 定のオーバーヘッドを要する . 個々のコンテンツ単位が 複雑でサイズが大きく，よく定義されたタグ集合を用意 できる場合は有用であるが, 会話コンテンツのように比 較的粒度がささ，インフォーマルな性格の強い会話量 子の表現をコンテンツの単位とする場合はタグ付けの有 効性よりもオーバーヘッドの方か問題になる .

この点で, コンテン゙部品を概念体系と関連づけるオ ントロジー技術に期待される.しかし, オントロジー技 術は, 比較的固定された概念体系の存在を前提としたも のであり，会話量子のようなインフォーマルでコンテキ ストへの依存性カ渱いコンテンツを取り扱うには大きな 困難汿想される .

テキスト検索技術は，インターネットのサーチエンジ ンで用いられており, タグ付けされていないデータに対 しても有用であるが，インフォーマルで文脈依存性の高 いコンテンツに適用することは困難である .

可視化技術は，これまでにあげた種々の困難を克服す る可能性をもつものである. しかし，従来の可視化技術 は大量て複杂倠な構造をもつデータを直感的かつ動的に表 
示して, データの理解を支援することに重点か㯰かれた ものであり，会話コンテンツを再利用を通して発展させ ていく過程はほとんど考慮されていない.

我々カ浗めるものは, 大量の会話コンテンツの全体像 を直観的に把握できるだけではなく，大量の会話コンテ ンツをユーザの記憶と連携させ , ユーザの外化された記 憶として, 生体的な脳内記憶にある記憶の痕跡と連携さ せて活用することを可能にするシステム, つまり, ユー ザとの関係性を継続的に発展させていくことのできるシ ステムでなければならない .

\section{2. コンテンツの供給のボトルネックの解消}

これまでの研究開発されてきた会話コンテンツ流通シ ステムでは, 技術が成熟のため, 会話の参加者ないし は観察者が会話の記憶や記録をもとに, 人手によって知 識カードとストーリを制作するという方式がとられてい た .

知識カードとストーリによるコンテンツ制作のコスト は小さいとはいえ，無視することはできない，例えば， 通常の講義における講義コンテンツの制作の場合は, 講 師にとってはかなりフォーマルな講演や外国語による講 義などでない限り，講義前に手間をかけて完全なコンテ ンツを用意しておこうという動機はなかなか生じない． 講義までにおよぞのストーリと関係資料を用意しておき， 講義力行われるときにはじめて乥れらを関連づけるロジ ックを外化するというスタイルがとられることが多い .

講義の後て記憶や記録をもとに講義の記録としてのコ ンテンツ制作を行うのはかなりの労力を要する作業であ る .すぐに次の講義の準備をしなければならないような 状況では, 弚うした「後乃向き」の作業への動機つけは 乏しい . 現実の講義の流れの中に講義の記録としてのコ ンテンツ制作のフェーズを組み込むためには, オーバー ヘッドをかなり小さくするか, 新たなインセンティブの 導入か必要であろう.

講義や会議ではじめて暗黙知か汒化されて観測可能に なる瞬間を捉えて記録し，乥こから極めて小さなオーバ ヘッドて会話量子化の表現力泩成されることか望ましい . 3.3. コンテンツのリアリティの確保

コミュニティ構成員による参加型のコミュニケーショ ンの実現は, 社会技術研究において達成すべき目標の一 つであると考えられる.しかし，これまで行ってきた実 証実験では，コミュニティコミュニケーションに参加す るユーザの比率は, コンテンツの視聴, 評価, 発信の順 に低くなり，管理者からの強い動機付けによるメッセー シ投稿はあっても，自発的なメッセージ投稿に至ること はまれであった .

ユーザの自発的な参加意欲を高めるための方策として， よりリアリティの高いコンテンツを制作できるようにす ることが考えられる．リアリティの高いコンテンツは魅
カの高いコンテンツであり, 弚れを受け取る側の意欲が 高まる.自分の発信したメッセージが多くの人々に受信 されることがわかると, 返報性によってコンテンツ制作 者の意欲か高まるであろう . さらに, 受信者からの質問 やコメントか寄せられるようになると, コンテンツ制作 がルーチン化し 好循環ができあがるものと考えられる .

メッセージのリアリティを高めるためには, 教室や会 議室のように，2 次的な情報に基づく会話力行われる場 ではなく，情報の源流である現場における会話の樣子を 伝えられるようにする必要がある。

3.4. 評価手法の必要性

我々の思考は, メディアを通して受け取る情報に大き く影響される.社会の構成員か依拠するコミュニケーシ ヨン基盤が健全なコミュニケーションや意思決定をもた らしているものであるかどうかを点検するための評価手 法の確立は社会技術の中心的な目標の一つであると考え られる。

コミュニケーション基盤の情報ッールとしての評価に つては, アンケート調査を中心とする定性調査や心理 学的手法を通した実験室実験などか試みられてきた。し かし,一般には調査には大きな労力と長時間を要し, 現 象か起きてから光のメカニズムか澥明されるまでの間に， かなりの時間遅れがあつた .

現在の情報化社会の変化のスピードの速さを考えると， 眼前て進行しつつある現象に対して, タイムリーに対応 できるようにする必要がある. 㫕のためには, コミュニ ケーションログやネットワーク上に掦載されたメッセー ジをリアルタイムに解析して社会現象を把握するための 手法の確立力望まれる .

評価手法は現象の理解だけでなく，システムデザイン にとっても大きな役割を果たす . 社会現象は再現性が しく, 結果の予想涃難であるので, 試行錯誤を重ねな がらシステム開発を続けていく必要がある.

\section{4. 会話型知識プロセスへの研究方略}

会話型知識プロセスモデルに基ついて知識創造プロセ スを支えるコミュニケーション基盤を実現するために， 没入型会話環境, 時空記憶外化システム, 会話コンテン ツ獲得支援, 会話コンテンツ高次利用支援, 社会知評価 パッケージの5項目を軸とする研究方略を提案する .

\section{1. 没入型会話環境}

没入型会話環境は, 教室や会議室などのプレゼンテー ションルーム環境における 2 次的な情報に基づく会話で はなく，題材の存在する現場て発生する 1 次的な情報に 基づく会話を捉え知識創造に利用することを目指してい る . 会話量子モデルに基ついて会話エージェントを使つ た非同期会話を行う点は従来の EgoChatやSPOC と同樣 であるが, 会話エージェントによる会話力現場の 2 次情 
報であるスライドにもとついて行われるのではなく，ユ 一ザもェージェントもシミュレートされた現場状況に没 入して会話を行う点が異なっている.

没入型会話環境は従来のプレゼンテーションルーム型 の会話環境をさらに発展させたものとして位置づけられ る. 従来のプレゼンテーションルーム型会話環境で , 会話エージェントの非言語コミュニケーション行為 (表 情やジェスチャ)は比較的限定されたものでよかったが， 没入型会話環境ではより多樣な行為か赇められる.また， 会話において参照される対象もプレゼンテーションルー ム型の会話環境では,「スライドの中」にあつたが, 没入 型会話環境では, 会話エージェントが置かれた環境全体 である . 表現力が高まる代わりに , コンテンツ制作のコ ストか増大するので, 弚れをいかに抑えるかか新たな課 題となる.

\section{2. 時空記憶外化システム}

時空記憶外化システムは, 情報の空間化・身体化とい う考え方に基ついている. Lakoff は, 人間の情報認知が 空間や身体とのメタファに基ついて行われていることを 指摘している ${ }^{5)}$. 情報や知識を空間や身体と関係付けて， 長期にわたつて持続的に外化していくことにより，大量 の情報に対してユーザと外化記憶の間に関係性か構築さ れて，過去に接した情報を自在に活用できるようにする ことを狙う.また類似の背景知識をもつ人々の間では， 情報の空間化・知能化に一定の共通性があり, 他人の作 つた外化記憶でも光の一部は比較的容易に解釈ができる だろう.

\section{3. 会話コンテンツ獲得支援}

会話型知識プロセスか洧効に機能するためには, 価値 の高い会話コンテンツが大量に供給される必要がある . 現場において生じる会話は質が少々悪くても価值は高い． 会話の現場で直接会話を収録できるようにするための技 術の研究開発を行う. 会話の状況に関する先験的知識を 使って獲得コストを低減することが考えられる．また， インターネットから供給される大量のコンテンツを利用 することが考えられる . 兴のためには, 書き言葉表現か ら話し言葉表現への变換などの技術を新たに開発する必 要がある.

\section{4. 会話コンテンツ高次利用支援}

会話コンテンツの量か増えて内容が多樣になれば, 目 指すコンテンツにューザをナビゲートする , コンテンツ の内容を比較する , 大量のコンテンツの中から傾向を抽 出する , 大量のコンテンツを要約する, 議論の趨勢を示 すなど, 高次利用のための機能への要請か高まる .こう した高次サービスを実現するためには，自然言語処理や データマイニングなどの手法を統合する必要がある .

\section{5. 社会知評価パッケージ}

社会知評価パッケージの研究では, 個人か社会構造の

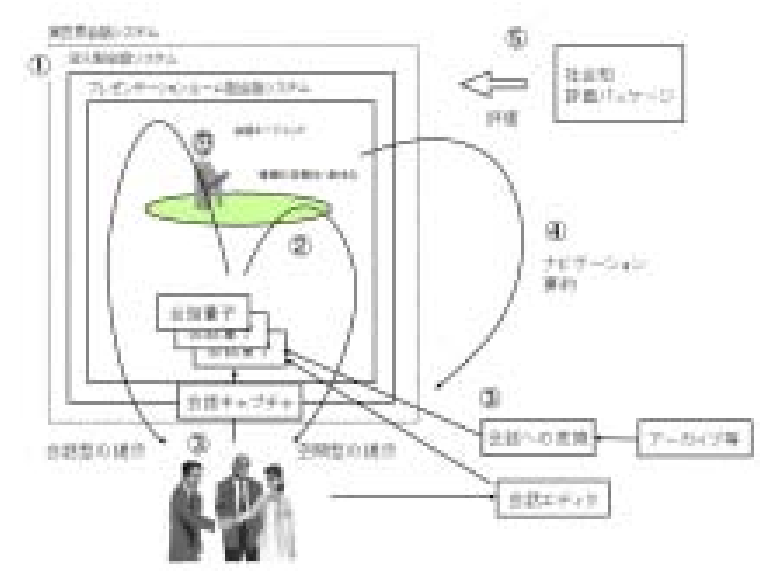

図 4 : 会話型知識プロセス研究の構造

なかて情報発信や情報獲得などの社会的行為を行う能力 や，集団が全体として持っている構成員の知的活動支援 能力を示す指標を社会知基準(social intelligence quantity, $\mathrm{SIQ})^{6}$ と呼び，产の定式化と測定をするためのパッケージ の開発を目指す . SIQ 評価パッケージを使ってコミュニ ケーション基盤使用時の利用者の心理状態を評価するこ とにより，コミュニケーション基盤の効果を測定できる ようにする . はじめは, 従来から研究の進んでいる尺度 をSIQ に組み込むことから検討し，次に光れがある程度 確立したところで, ロク解析などリアルタイム性につな がる SIQ 評価方法の研究開発を行う.

\section{6. 会話型知識プロセスへの研究方略の全体像}

上に述べた5つの研究項目を用いた会話型知識プロセ スの研究方略の全体像を図 4 に示す. 没入型会話環境の 研究 (図中(1) では, 会話環境自体の魅力を向上させて ユーザの自発的参加を促進することをめざす．リアリテ イをさらに高めるためには , 会話の現場で参加者を支援 する実世界会話環境がより適切であるが, 光のためには より大掛かりな道具立てか必要であるので, 将来の課題 として位置つけている.一方, 没入型会話噮境の研究開 発は，現場に行かなくても現場の状況を把握したいとい う別の要請にも応えようとするものであり, 有用性が高 い. 時空記憶外化システムの研究 (図中(2)) では,これ まて会話による情報の時系列的なプレゼンテーションに 偏つていた会話エージェントシステムに , 会話量子の集 まり全体を俯瞰できるようにする空間的なプレゼンテー ション機能を与えて , ユーザが大量のコンテンツをより 容易に把握できるようにすることを目指す . 会話コンテ ンツ獲得支援の研究 (図中(3))で, 現場やドキュメン トアーカイブからの会話コンテンツ獲得ができるように して , コンテンツ供給のボトルネックの解消をめざす . 会話コンテンツ高次利用支援の研究 (図中(4)) は, 大量 の会話コンテンツの理解の支援を志向した研究として位 置つけられる . 社会知評価パッケージの研究 (図中(5) では, 会話型知識プロセスの研究における樣々な研究の 
評価手法の開発に取り組む．

以下の 5〜9節では，上に述べた方向への取り組みの現 状を概括する.

\section{5. 没入型会話環境 IPOC}

IPOC (Immersive Public Opinion Channel)システム ${ }^{78}$ は， 会話の行われる状況のなかにユーザとエージェントの双 方を組み込んで当事者感を高めることにより，効果的な 体験の伝達ができるようにしたシステム (開発中) であ る.没入環境に会話量子を表現した知識カードを埋め込 む方式を採用することによって，コンテンツ制作コスト の低減を図っている。

IPOC では, ユーザとエージェントを囲む円筒形の局 面の表面に遠景を張り込んだパノラマ映像環境を生成し， そのなかに複数の会話エージェントの歩行領域を作り出 すとともに , パノラマ映像のなかの必要な箇所に会話量 子を表現した知識カードをタグとして埋め込むことによ り没入型会話環境を近似的に表現する (図 5a).

没入環境の会話コンテンツの制作は, 従来のプレゼン テーションルーム型会話環境のために用いたものと同樣 である (図 $5 b$ ). 没入環境におけるユーザとエージェン トの会話は，環境を表示した大画面の前て音声認識，ス クリーンの前に置かれた操作オブジェクト, キーボード を用いて行う、会話エージェントのジェスチャは, 自然 言語処理の手法によって発話内容を解析し, 会話の状況 と対照することにより自動的に生成される (図 5c).

\section{6. 知球システム}

知球システム(Sustainable Knowledge Globe, SKG $\left.\mathrm{S}^{9}\right)$ は球 面上にコンテンツを配置することによって情報の空間化 と身体化を図った時空記憶外化システムの試みである (図6).

ユーザは会話的プレゼンテーションのためのストーリ を表すアイコンを球面上に配置して , 自分の知識の景観 を構成し，漸次谷の改良と拡張を行うことができる.球 面上には獲得した情報を置くだけでなく，目印となるラ ンドマークやメモを挿入したり，アイコンをリンクで結 んで, アイテム間の関係をたどるための「路」をつくっ たりすることによって, 自分の世界を構築し, あとで再 訪したときの助けにすることができる .

また , ユーザは, 知球を遠くから眺めて自分の有する 情報の全体像を俯敢的に眺めることができるだけでなく， ある知識に焦点をあてて知球の表面に降り立ち, 当事者 として光の内容を吟味したり，近傍の知識を探訪したり することができる .

\section{7. 会話コンテンツ獲得}

会話コンテンツ獲得の研究は, キャプション付ビデオ

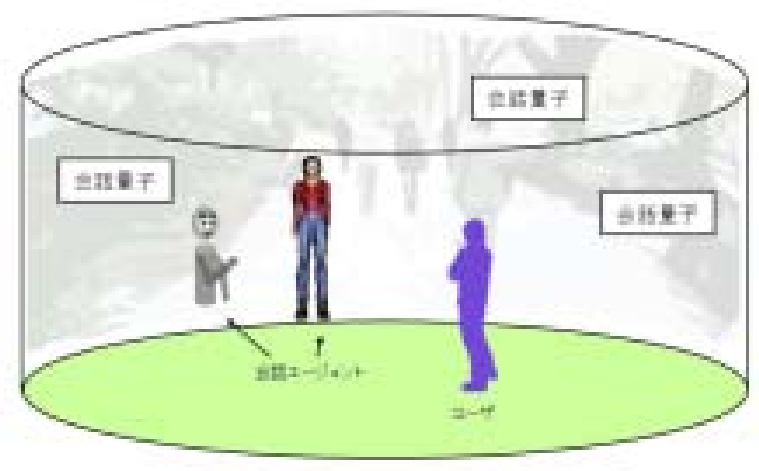

(a) 没入型会話環境の概念

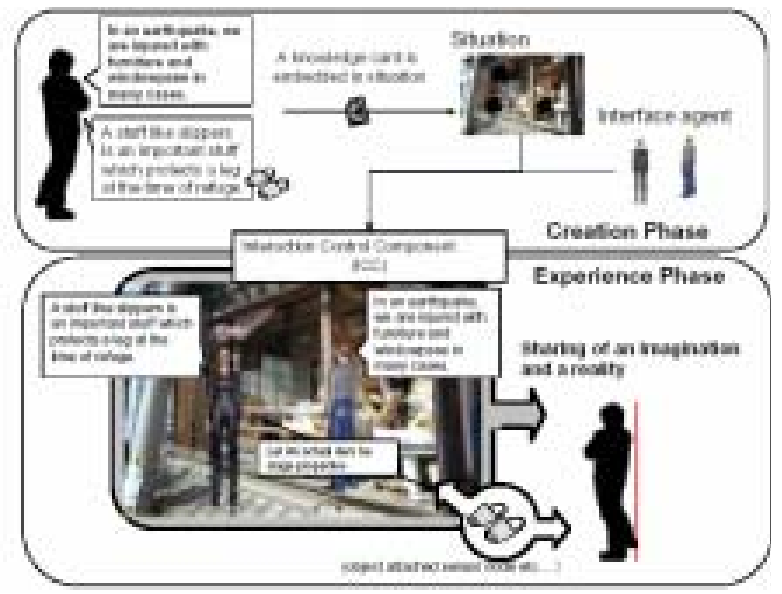

(b) コンテンツ生成から会話まで流れ

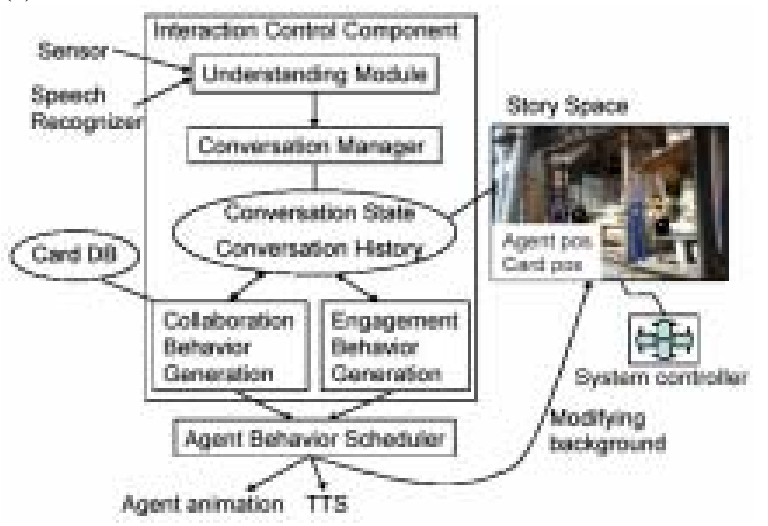

(c) ユーザとの会話の実行のための処理の概要

图 5 : 没入型会話噮境 IPOC

などか叫録された既存の映像アーカイブからの会話コン テンツ獲得を目指したアプローチと，現場での会話コン テンツ獲得を目指したアプローチに大別される．

黑橋, 柴田らは, 写実性の高い映像を中心にした会話 コンテンツの獲得と利用をめざした先進的な映像インデ クス自動付与・対話的映像メディア技術の開発と, 映像 情報と言語情報の統合的解析技術の開発に取り組んでい $3^{10)}$.これによって , 映像を会話型コンテンツに変換す るための技術がきく進展した .

角らは, タグのつけたセンサーの埋め込まれた室内に おける会話イベントを, 会話パターン知識に基づて自 
動的に検出・分類し，展示会における体験記録の自動的 な要約や提示の手法を提案・実装している ${ }^{11)}$.

中村は , マルチモーダル教示コンテンツにおいて映像 処理技術と自然言語処理技術を連携させて, 言語情報に 加えてシーンチェンジや顔画像認識などの情報を統合す ることによって, 教示発話の談話構造の自動解析が大き く改善されることを明らかにした ${ }^{12)}$.

\section{8. 会話コンテンツ高次利用}

会話コンテンシ高次利用のアプローチとして , ナビゲ ーション ,テキスト統計による社会における討論の解析， 論議の構造の解析などの研究力行われている.

中川らは, インターネット上で公開されている複数情 報源にまたがる同じトピックの記事を重複なく読んだり， 逆に比較検討したりすることを可能にする横断検索機能 と，関連する記事をいもづる式に検索することを可能に するドリフト機能を併せ持つシステム「いもなび」を開 発した。「いもなび」によって，視点や立場の違いによる 記事内容の異なりに依存せず，問題を多面的に捉えて， 乥の全体像を段階的に把握することが可能になった ${ }^{13)}$.

福原らは, Weblog のデータを自動的に収集し，与えら れた話題に関する社会の関心の高さや時間的な推移をリ アルタイムて解析できるシステムを開発した(図 7) .この システムを用いて ,Weblog におけるキーワードの変化の パターンを調べ, 図 8 に示すように, 周期型 , 漸増型 , 敏感型, 減衰型, 光の他の 5 つのパターンに分類できる ことを指摘している ${ }^{14)}$.

堀田は, 理論指標 NCI (Node Concentration Index)を提案 し，政策論議の議事録のなかから最も議論か集中してい るところを抽出し，表示する方法を開発した .この手法 は国際協力事業団 (現・国際協力機構) の委員会におけ る情報公開に実際に適用された ${ }^{15)}$.

\section{9. 評価パッケージ}

松村らは, 社会知を人間力社会的枠組みの中で共同し て知識を保持し, 行動を調整する能力として定義し こ こ れまて個別的に扱われる傾向にあった定性的評価と定量 的評価を総合して, SIQ (Social Intelligent Quantity)として 総合的に定式化する試みを進めている.SIQ は個人の社 会的能力を既定する SIQ-Personal と, 個人が属する集団 の状態を既定する SIQ-Collective から構成される 現在の ところ, 情報欲求尺度, コミュニティへの参加意図, ロ ク解析による行動指標から構成される SIQ-Personal と， コミュニティの活動量 ,コミュニケーションの進行傾向 , 情報間の関係から構成される SIQ-Collective か提案され ている ${ }^{16)}$.

\section{0. 長期的な展望}

社会技術研究は, 社会力㵍題を抱える限り存続するテ

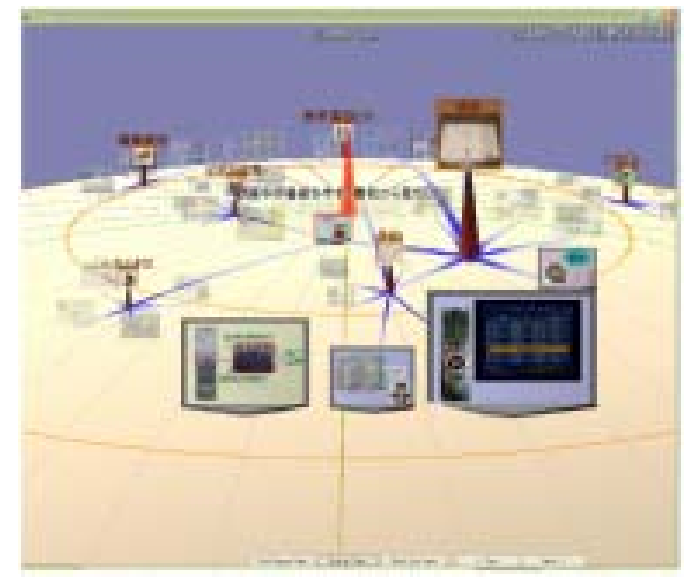

図 6 : 知球システムの画面スナップショット ${ }^{8)}$

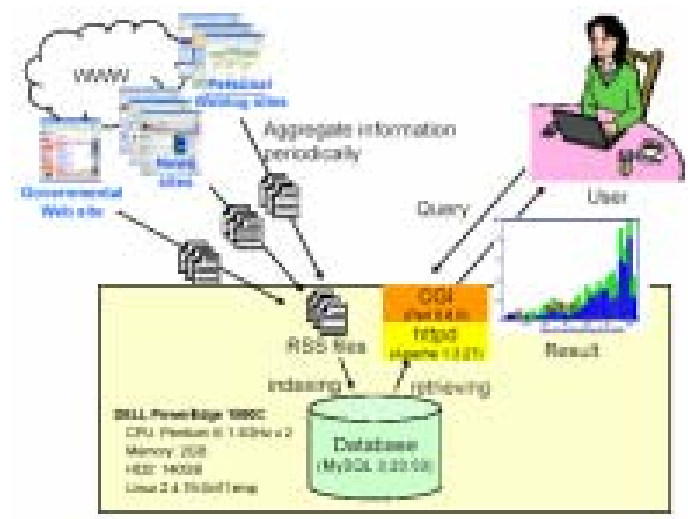

図 7: Weblog 理解支援システム
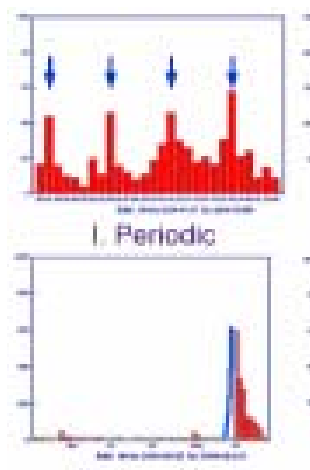

III. Sensitive
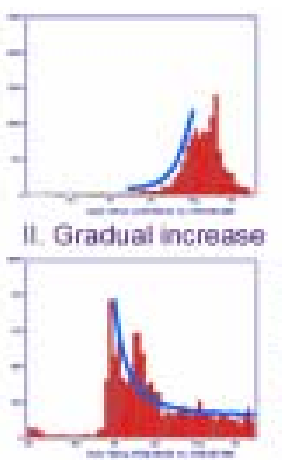

IV. Trailing

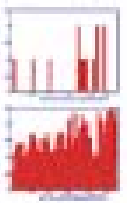

v. Other

図 8:Weblog 理解支援システムを用いて発見された関心の推 移のパターン ${ }^{14)}$

一マであるので，より長期的な課題を明確にし，長期的 な視野のもとでの取り組みを並行して進めていく必要が ある.この節では, 会話型知識プロセスに関わる長期課 題として, 実世界会話システム, 社会的人工物, エンタ 一テインメントコンピューティングとの融合について議 論する。

実世界会話システムとは, 会話て題材となる現象力発 生し, 知識が適用される現場において適用される会話支 援システムである. 現在研究開発か進んでいるユビキタ ス情報処理技術を用いて 環境のなかに IC タグのような 微小な情報識別装置を埋め込み, センサーネットワーク 
と連動させることによって，これまて困難であつた実世 界でのオブジェクトのリアルタイム認識への見通しが得 られた .すべての人工物にIC タグがけられるようにな るまでには光れほど時間を要しないだろう，乥うなれば， IC タグを用いた認識と, 従来のパターン認識技術とセン サ融合技術による認識を統合して, かなり高精度で実世 界の状況を認識することか可能になるであろう．

ユビキタス情報処理環境か実現され，エージェントが 実世界の状況認識に基ついてユーザと会話ができるよう になれば, 弚の有用性は非常に高いものとなる . 従来手 法ては，没入型会話環境によってユーザの経験を伝える ことができても，没入型会話環境と実世界の対心付けは ユーザに依存せざるをえなかった . 弚のため, ユーザが パニック状況に陥って状況を誤認したり，没入型環境と の対応付け確立できなくなってしまうと, ユ一ザへの 支援はできなくなってしまうのであるが, 実世界会話シ ステムでは光のような問題は生じにくい.

人工物や人工環境に社会的な知能を持つチップを埋め 込んで, 人間や他の人工物との間て協調や交渉などの社 会的行為ができるようにしたものを社会的人工物という 社会的人工物か実現されると，会話によって人間とコミ ユニケーションするだけでなく, 物理環境に直接作用し て, 社会の安全と安心に貢献することができるようにな るだろう。

社会的人工物の例として，

- 製造者と消費者の意図の交換を可能にする電化製 品 (消費者は高度な機能を引き出せ, 製造者は消費 者の二ーズを知る)

一歩行者や他の自動車に気を配り，マナーがよく，安 全な半自律走行自動車

- 人の行動に合わせて形状を変える建物

- 非常時に人間の行動を誘導する乗り物

一環境における違法行為を監視し，抑止する人工物 などが考えられる .これらは, 単に利便性をもたらすだ けでなく, 社会をより安全で安心できるものに変えるた めの主要な手段になるだろう .

社会的人工物を実現するために求められる主たるブレ 一クスルーは, 人間と人工物の意思疎通を確立する技術 ${ }^{177}$ と, 人間と人工物の社会的行為を認識し, 社会的な行 動を生成する技術の確立である.

エンターテインメントコンピューティングとの融合は， 社会技術の成果を社会に浸透させるための一つの方策で ある、一般に,メッセージを社会に伝えるためには,人々 の関心を引いた上でメッセージを伝え, 弚れを受容して もらう必要がある . 人々の関心を引くためには , 人々の 生活の深部まで入り込んで, メッセージを伝えるタイミ ングをうまく捉えなければならない．競争過多な知識社 会において人々の関心を捉えるためには 人をもてなし，
共感を得なければならない .この意味では日常における 知識伝達がしばしばゲームやクイズの形をとり，また , エデュテインメントといった概念力語られるのは当然で あるといえる、コンテンツ制作では, 伝えたいメッセー ジをエンターテインメントにうまく織り込む技術か求め られる。

\section{1. まとめ}

本論文では，まず，従来の会話型知識プロセス支援技 術を会話量子化に基づく会話コンテンツ流通システムを 実現する試みであると特徵づけた . 次に , このアプロー チを有効に機能させるためには, 大量の会話コンテンツ の理解の支援 ,コンテンツの供給のボトルネックの解消， コンテンツのリアリティの確保, 評価手法の確立が必要 であることを指摘した，次に，没入型会話環境，時空記 憶外化システム, 会話コンテンツ獲得支援, 会話コンテ ンツ高次利用支援, 社会知評価パッケージからなる, 会 話型知識プロセス支援技術確立のための研究方略を提案 し, この方向での関連研究を概括した . 最後に, 実世界 会話システム, 社会的人工物, エンターテインメントコ ンピューティングとの融合を長期的な課題として提示し た。

今後の課題の一つとして , 本論文 4 節を中心に述べた 研究方略の限界を明確にすることがあげられる . 光のた めにも, 本研究の取り組みを可能な限り透明化して, 誰 にでも理解し評価できるようにしたい.

\section{参考文献}

1) 西田豊明(2003)：「社会技術を支える先進的コミュニケー ション基盤としての会話型知識プロセス支援技術」、『社 会技術論文集』1,48-58 .

2) Yukiko I. Nakano, Toshiyasu Murayama, and Toyoaki Nishida (2004): Multimodal Story-based Communication: Integrating a Movie and a Conversational Agent, IEICE Transactions Information and Systems, Vol. E87-D, No. 6, pp. 1338-1346.

3) 久保田 秀和, 黑橋 禎夫, 西田 豊明(2003) : 知識力ードを 用いた分身エージェント，『電子情報通信学会論文誌ソフ トウェアェージェントと午の応用論文特集』, vol. J86-D-I, No.8, pp.600-607.

4) 福原知宏, 松村憲一, 近間正樹, 西田豊明(2003): コミュニ ティ支援システムにおけるコミュニティ分析支援機能,

『電子情報通信学会論文誌(D-I)』, Vol.86, No.11, pp.838-847

5) George Lakoff (1987): Women, Fire, and Dangerous Things, The University of Chicago, (訳書 : ジョージ・レイコフ : 池上嘉彦 , 川上誓作 他訳(1993): 認知意味論, 紀伊国屋 書店, 1993) 
6) Koji Yamashita and Toyoaki Nishida (2002): SIQ (Social Intelligence Quantity): Evaluation Package for Network Communication Tools, APCHI 2002 -- 5th Asia Pacific Conference on Computer Human Interaction - Beijing, China, 2002.

7) Toshihiro Murayama, Yukiko Nakano and Toyoaki Nishida (2004): Participatory information sharing system by using an interface agent and a situation, in: Czeslaw Danilowics (ed.): Multimedia and Network Information Systems -- Proceedings of 1st International Workshop on Intelligent Media Technology for Communicative Intelligence, vol. 2, pp. 87-93

8) Yukiko I. Nakano, Toshiyasu Murayama, and Toyoaki Nishida (2004): Engagement in Situated Communication by Conversational Agents, in: Czeslaw Danilowics (ed.): Multimedia and Network Information Systems -- Proceedings of 1st International Workshop on Intelligent Media Technology for Communicative Intelligence, vol. 2, pp. 95-101

9) Toyoaki Nishida, Yasuyuki Sumi, Hidekazu Kubota, and Hung-Hsuan Huang (2004): A Computational Model of Conversational Knowledge Process, in: Czeslaw Danilowics (ed.): Multimedia and Network Information Systems -Proceedings of 1st International Workshop on Intelligent Media Technology for Communicative Intelligence, vol. 2, pp. 103-112

10) Tomohide Shibata, Daisuke Kawahara, Masashi Okamoto, Sadao Kurohashi, and Toyoaki Nishida (2003): Structural Analysis of Instruction Utterances, In Proceedings of Seventh International Conference on Knowledge-Based Intelligent Information and Engineering Systems (KES2003), pp.1054-1061

11) Y. Sumi, T. Matsuguchi, S. Ito, S. Fels, and K. Mase (2003): Collaborative capturing of interactions by multiple sensors, Ubicomp 2003 Adjunct Proceedings, pp.193-194

12) M.Ozeki, H.Izuno, M.Itoh, Y.Nakamura, Y.Ohta (2003): Object Tracking and Task Recognition for Producing Intaractive Video Content --- Semi-automatic indexing for QUEVICO, Proc. Seventh Int'l Conference on Knowledge-Based Intelligent Information \& Engineering Systems, pp.1044-1053

13) 山田岡川一, 大熊耕平, 増田英孝, 中川裕志 (2003) : 複数 新聞記事サイトの横断検索とトピックのドリフト支援シ ステム，『社会技術論文集』1,100-105

14) Tomohiro Fukuhara and Toshihiro Murayama (2004): An analysis tool for understanding social concerns using Weblog articles, in: Czeslaw Danilowics (ed.): Multimedia and Network Information Systems -- Proceedings of 1st International Workshop on Intelligent Media Technology for Communicative Intelligence, vol. 2, pp. 45-54

15) 堀田昌英, 榎戶輝揚, 岩橋伸卓 (2003) : 多元的議論構造 の可視化手法 , 『社会技術論文集』1,67-76
16）松村憲一，西田豊明(2004)：「コミュニケーションシール 評価手法の構築」,『社会技術論文集』2, 投稿中 .

17)西田豊明(2004)：人とロボットの意思疎通, 特集「知能口 ボットの技術 : 人工知能からのアプローチ (後編)」, 『情 報処理』, 44 巻 2 号, pp. 1214-1220

\section{謝辞}

本研究は、社会技術研究システム ミッション・プロ グラム「安全性に係わる社会問題解決のための知識体系 の構築」(平成1 3〜1 4年度は日本原子力研究所の事業、 平成1 5 年度からは科学技術振興事業団の事業) の研究 として行われた。会話型知識プロセスの研究の遂行にご 協力をいただいているプロジェクトの諸氏に感謝します． 


\title{
The Strategy for Conversational Knowledge Process Support Technologies for Social Technologies
}

\author{
Toyoaki NISHIDA ${ }^{1}$
}

${ }^{1} \mathrm{Ph} . \mathrm{D}$. (Engineering) Professor, Kyoto University, Dept. of Intelligence Science and Technology

(E-mail:nishida@i.kyoto-u.ac.jp)

Social technologies can be characterized as a process-centered knowledge creation environment in the complex and dynamical society. The conversational knowledge process support technologies attempt at realization of process-centered knowledge creation support system in a community, based on the central use of conversation which is the most natural communication means for people. In this paper, I characterize conversational knowledge process support technologies as a research on a conversation content distribution system based on the idea of conversation quantization. I point out that support for grasping a large collection of conversation contents, resolution of the bottleneck of content provision, realization of the reality of content, and the establishment of the evaluation method are all necessary for our approach to be effective. I propose a strategic research plan with particular emphasis on immersive conversation environment, externalized temporal-spatial memory system, advanced applications of conversational knowledge utilization, social intelligence evaluation package, and I review work towards on this direction.

Key Words: Conversational knowledge process, conversation quantization, immersive conversation environment, externalized temporal-spatial memory system, advanced applications of conversational knowledge utilization, social intelligence evaluation package 